Research article

\title{
EVALUATION OF THE EFFECTIVENESS OF SELECTED TREATMENTS OF NOSEMA SPP. INFECTION BY THE HEMOCYTOMETRIC METHOD AND DUPLEX PCR
}

\author{
MICHALCZYK Maria*, SOKÓ£ Rajmund, KOZIATEK Sylwia \\ Department of Parasitology and Invasive Diseases, Faculty of Veterinary Medicine, University of \\ Warmia and Mazury in Olsztyn, Poland
}

(Received 11 April; Accepted 18 September 2015)

\begin{abstract}
Recent years have witnessed an increase in the mortality of honey bees in many regions of the world. The observed decrease in the bee population results from a combination of factors, and microsporidian parasites Nosema apis and N. ceranae are among the main contributors. Those parasites cause a microsporidian infection that shortens the lifespan of bees and reduces the productivity of bee colonies. The aim of this study was to evaluate the effectiveness of Nozevit, Api Herb and ApiX (acetylsalicylic acid + Artemisia absinthium L. extract) in the control of infections caused by Nosema spp. in a field experiment. Two groups of worker bees were evaluated - hive bees and forager bees returning to the hive. The effect of the analyzed therapies on the number of spores and the microsporidia species were analyzed by the hemocytometric method and duplex PCR. A statistical analysis revealed that the applied treatments had reduced the number of spores by $31.15 \%$ on average. In hive bees, Nosema spp. infection was most effectively reduced by Nozevit (67.85\%) and ApiX (63.36\%). Coinfections ( $N$. ceranae and N. apis) were affirmed in all bee samples before treatments. However, after the treatments, single infection of $N$. apis and $N$. ceranae were detected. The tested treatments were more effective in the control of $N$. apis than N. ceranae.
\end{abstract}

Key words: Nosemosis control, N. apis, N. ceranae, honey bees

\section{INTRODUCTION}

The global increase in honey bee mortality rates is associated with the widespread use of crop protection chemicals, monoculture farming and various diseases affecting bee colonies. The leading causes of adult bee diseases in honey bees are two microsporidian species of the genus Nosema (kingdom Fungi, class Microsporidia, family Nosematidae) - Nosema apis and N. ceranae along with Varroa destructor mite, honey bee viruses and their interactions [1-3]. These parasites cause microsporidiosis (nosemosis), an infection that spreads per os with contaminated food. The pathogens

\footnotetext{
*Corresponding author: e-mail: maria.michalczyk@uwm.edu.pl
} 
proliferate mainly in mid-intestinal epithelial cells [4]. In worker bees, microsporidian infections inhibit the development of hypopharyngeal glands that secrete royal jelly, thus disrupting the feeding of queens and the brood [5]. N. apis infections shorten the lifespan of worker bees and queen bees, leading to ovarian damage and infertility in queens [6]. The disease lowers honey production and can reduce brood by even $50 \%$. N. ceranae infection develops rapidly and may be highly lethal. Bees die within 8 days after experimental exposure to $N$. ceranae under laboratory conditions [7]. However, in mixed infections ( $N$. apis and $N$. ceranae), no competitive advantage was affirmed for $N$. ceranae for either infectivity or spore growth $[8,9]$. The symptoms of $N$. ceranae infections in bee colonies are visible throughout the year, whereas the disease spread by $N$. apis disappears in the warm months of the year. Symptoms traditionally as fecal marks, sick crawling bees attributed to $N$. apis infection were observed in the majority of $N$. ceranae infected bees [10]. In most cases, the disease spreads when healthy and infected colonies are merged and when contaminated hive equipment and food reserves are used. Young queen bees and worker bees from apiaries affected by nosemosis can also be a source of disease [11,12].

The main challenge facing beekeepers is to limit the spread of sporozoan infections in bee colonies. The use of the antibiotic Fumagillin DCH is not licensed in most countries of the European Union due to the side effects of its commercial formulation, like genotoxic and tumorigenic properties [13,14] and stability in honey [15]. The most popular alternative treatments against nosemosis including Api Herb, Nozevit, Feed Gold, Protofil and Nosestat, are not always effective [16-18].

The aim of this study was to evaluate the effectiveness of three preparations in the control of infections caused by Nosema spp. in a field experiment. Two preparations are already commercialized (Nozevit, and Api Herb), and the third ApiX (acetylsalicylic acid + wormwood Artemisia absinthium L., extract) is currently undergoing pre-clinical trials.

\section{MATERIALS AND METHODS}

\section{Honey bee colonies, test treatments and experimental design}

In spring, the presence of Nosema spp. spores and Nosema species were determined in samples of winter hive debris from a commercial apiary, Poland $\left(53^{\circ} 47^{\prime} \mathrm{N}, 20^{\circ} 30^{\prime} \mathrm{E}\right)$ (200 bee colonies kept in Dadant hives) by the microscopic method. To evaluate the effectiveness of the tested treatments an experimental apiary of 25 bee colonies was established. The outward symptoms of nosemosis were not observed in the analyzed colonies. All hives/groups were in similar health conditions before the experiment. The bees were divided into five groups. Group $\mathrm{N}$ was treated with herbal product Nozevit International ${ }^{\circ}$ in sugar syrup (1:1 water/sugar) at $3 \mathrm{ml} / 41$ of syrup. Group AH had received herb-based preparation ApiHerb (Chemicals Laif srl, Italy) at $4 \mathrm{~g} / 50 \mathrm{ml}$ of syrup. Group AX administered ApiX (acetylsalicylic acid + extract of wormwood Artemisia absinthium L.), at $1.5 \mathrm{mg} / 101$ of syrup. Two control groups were included 
in the study, one fed sugar syrup (Cs) and the other that was not additionally fed or medicated $(\mathrm{C} 0)$. The treatments and sugar syrup were administered 4 times, every 2 days, in early April, at $0.5 \mathrm{l} /$ colony in feeders that enable feed intake control.

The effect of the test treatments on Nosema spp. was analyzed by the hemocytometric method with the use of a modified Neubauer chamber and by duplex PCR. Sixty hive bees $(\mathrm{HB})$ were randomly harvested from the brood comb in the center of the nest and 60 forager bees (FB) returning to the hive were randomly collected from the hive entrance using a special catching device. First samples were collected 7 days after the last administration of feed and test treatments. Overall, samples were taken 5 times, every 7 days around noon. Number of spores was determined in accordance with the guidelines of the Office International des Epizooties [19].

\section{Duplex PCR}

To identify Nosema spp. all samples were analyzed using duplex PCR method and species - specific primers (321APIS-FOR/REV for detection of N. apis and 218MITOCFOR/REV for detection of $N$. ceranae) designed by Martin-Hernandez et al. [20]. Genomic DNA was isolated from filtered and centrifuged (800 g for 6 minutes) sample suspensions using the Genomic DNA Mini Kit (A\&A Biotechnology, Gdynia, Poland). Purified DNA was stored in test-tubes at a temperature of $-20^{\circ} \mathrm{C}$ for further analysis. Duplex PCR reaction was carried out using HotStarTaq Plus Polymerase (Qiagen). The reaction mixture of $20 \mu \mathrm{l}$ comprised around $120 \mathrm{ng}$ isolated DNA (from 1 to $3 \mu \mathrm{l}$ ), 10 $\mu$ l HotStarTaq Plus Master Mix 2x, $2 \mu$ l CoralLoad Concentrate $10 \mathrm{x}$, and $0.1 \mu \mathrm{l}$ of each primer (with a final concentration of $0.5 \mu \mathrm{M}$ ). The reaction was carried out in the Mastercycler thermocycler (Eppendorf). PCR commenced with initial denaturation for 5 minutes at $95^{\circ} \mathrm{C}$. The reaction mixture was then cycled 35 times, in the following steps: denaturation at $94^{\circ} \mathrm{C}$ for 45 seconds, primer annealing at $55^{\circ} \mathrm{C}$ for 45 seconds and extension at $72^{\circ} \mathrm{C}$ for 1 minute. The last reaction was followed by final chain synthesis at $72^{\circ} \mathrm{C}$ for 10 minutes. The products of the duplex PCR reaction were separated by electrophoresis in $2 \%$ agarose gel in $1 \mathrm{x}$ TAE at 5 $\mathrm{V} / \mathrm{cm}$. The size of the obtained products was evaluated by comparison with the GeneRuler 100 bp Plus DNA Ladder (Fermentas) molecular size marker. Ethidium bromide was added to the gel at $0.5 \mu \mathrm{g} / \mathrm{ml}$ to visualize the resulting DNA fragments of Nosema spp. Electrophoresis results were archived using the GelDoc (Bio-Rad) gel documentation system.

The results were processed in the Statistica 9.0 application for Windows using one-way ANOVA and Duncan's test ( $\mathrm{p} \leq 0.05$ and $\mathrm{p} \leq 0.01)$.

\section{RESULTS}

Based on hemocytometric analysis of 25 bee colonies, the average number of Nosema spp. spores in HB from winter hive debris ranged from $13.74 \times 10^{4}$ in group $\mathrm{N}$ to 
$25.62 \times 10^{4}$ in group Cs (Table 1). The average number of Nosema spp. spores in HB collected from the brood comb before treatment ranged from $18.36 \times 10^{4}$ in group AH to $28.0 \times 10^{4}$ in group N. A significant decrease in Nosema spp. spore counts was noted in HB from all groups as early as during the first analysis after 4 applications of Nozevit, Api Herb, ApiX and sugar syrup (7 days after the last application). The decline in spore counts was maintained throughout the experiment (Table 1).

Table 1. Average number of Nosema spp. spores in hive bees (HB) x $10^{4}$

\begin{tabular}{|c|c|c|c|c|c|c|c|c|}
\hline \multirow{3}{*}{ Group } & \multirow{3}{*}{ Parameter } & \multicolumn{7}{|c|}{ Average spore count in $\mathrm{HB}$} \\
\hline & & \multirow{2}{*}{$\begin{array}{l}\text { Winter } \\
\text { hive debris }\end{array}$} & \multirow{2}{*}{$\begin{array}{c}\begin{array}{c}\text { Before } \\
\text { treatment }\end{array} \\
0 / 100 \% \\
\end{array}$} & \multicolumn{5}{|c|}{$\begin{array}{l}\text { After the administration of treatment } \\
\text { and sugar syrup in test No. }\end{array}$} \\
\hline & & & & I & II & III & IV & $\mathbf{V}$ \\
\hline \multirow{2}{*}{ N (Nozevit) } & $\bar{x}$ & 13.74 & $28.0^{A}$ & $9.00^{\mathrm{B}}$ & $7.28^{\mathrm{B}}$ & $0.72^{\mathrm{B}}$ & $0.16^{\mathrm{B}}$ & $0.20^{\mathrm{B}}$ \\
\hline & SD & 7.29 & 22.16 & 7.30 & 11.71 & 0.92 & 0.17 & 0.35 \\
\hline \multirow{2}{*}{ AH (Api Herb) } & $\bar{x}$ & 25.52 & $18.36^{\mathrm{A}}$ & $12.64^{\mathrm{a}}$ & $3.00^{\mathrm{B}}$ & $0.43^{\mathrm{Bb}}$ & $0.80^{\mathrm{Bb}}$ & $2.65^{\mathrm{B}}$ \\
\hline & SD & 10.15 & 9.36 & 14.26 & 4.85 & 0.57 & 1.27 & 4.36 \\
\hline \multirow{2}{*}{ AX (ApiX) } & $\bar{x}$ & 24.02 & $20.20^{A}$ & $7.40^{\mathrm{B}}$ & $6.84^{\mathrm{B}}$ & $1.12^{\mathrm{B}}$ & $0.88^{\mathrm{B}}$ & $0.32^{\mathrm{B}}$ \\
\hline & SD & 9.47 & 7.92 & 7.54 & 8.38 & 1.55 & 1.86 & 0.41 \\
\hline \multirow{2}{*}{ Cs (syrup) } & $\bar{x}$ & 25.62 & $23.92^{\mathrm{Aa}}$ & $11.48^{\mathrm{b}}$ & $11.40^{\mathrm{b}}$ & $9.14^{\mathrm{B}}$ & $2.60^{\mathrm{B}}$ & $1.68^{\mathrm{B}}$ \\
\hline & SD & 14.36 & 11.62 & 12.85 & 4.08 & 1.22 & 0.57 & 0.72 \\
\hline \multirow{2}{*}{$\mathrm{CO}$} & $\bar{x}$ & 22.90 & $21.34^{\mathrm{A}}$ & $10.72^{\mathrm{Ba}}$ & $5.94^{\mathrm{BCb}}$ & $1.32^{\mathrm{Cc}}$ & $2.32^{\mathrm{C}}$ & $1.06^{\mathrm{Cc}}$ \\
\hline & SD & 9.44 & 6.98 & 2.79 & 2.66 & 1.40 & 1.02 & 0.73 \\
\hline
\end{tabular}

$\mathrm{x}$ - arithmetic mean, $\mathrm{SD}$ - standard deviation. Homogenous groups marked with various letters differ significantly: uppercase letters - at $\mathrm{p} \leq 0.01$, lowercase letters - at $\mathrm{p} \leq 0.05$

Before treatment, the number of spores in FB was in the range of $10.62 \times 10^{4}$ in group AH to $16.14 \times 10^{4}$ in group N. During the first test after treatment, the number of spores increased in groups $\mathrm{N}, \mathrm{AH}, \mathrm{AX}$ and $\mathrm{Cs}$, whereas a significant decrease was noted in group C0 (Table 2). Spore counts decreased in all groups on succeeding dates of analysis. The greatest decrease (put the extract number and significance level) was observed in group $\mathrm{N}$, followed by groups $\mathrm{AH}, \mathrm{CO}$ and $\mathrm{Cs}$.

A comparison of spore counts in $\mathrm{HB}$ and $\mathrm{FB}$ in the analyzed groups did not reveal significant differences. A significant increase in the number of spores infecting FB relative to $\mathrm{HB}$ was observed only during the first analysis in groups $\mathrm{N}$ and $\mathrm{AH}$. $\mathrm{A}$ significant increase in the number of spores was observed in HB from group Cs in tests I, II and III, and in HB from group CO - in test III.

The effectiveness of the analyzed treatments was evaluated by the hemocytometric technique based on the number of spores, but this method was not used to identify Nosema pathogens to species level because it does not enable species identification [21]. Microsporidia species were validated by duplex PCR. 
Table 2. Average number of Nosema spp. spores in forager bees (FB) x $10^{4}$

\begin{tabular}{lccccccc}
\hline & & \multicolumn{5}{c}{ Average number of spores in FB } \\
\cline { 3 - 8 } Group & Parameter & $\begin{array}{c}\text { Before } \\
\text { treatment }\end{array}$ & \multicolumn{5}{c}{ After the administration of treatment and sugar } \\
& & $\mathbf{0 / 1 0 0 \%}$ & $\mathbf{I}$ & II & III & IV & V \\
\hline \multirow{2}{*}{$\mathrm{N}$ (Nozevit) } & $\bar{x}$ & 16.14 & $24.60^{\mathrm{a}}$ & $6.48^{\mathrm{b}}$ & 7.88 & $0.12^{\mathrm{b}}$ & $1.45^{\mathrm{b}}$ \\
& $\mathrm{SD}$ & 13.74 & 24.45 & 12.17 & 4.66 & 0.27 & 1.88 \\
$\mathrm{AH}$ (Api Herb) & $\bar{x}$ & 10.62 & 11.36 & 9.70 & 2.50 & 2.30 & 0.95 \\
& $\mathrm{SD}$ & 6.57 & 10.65 & 14.63 & 1.45 & 3.98 & 1.19 \\
$\mathrm{AX}$ (ApiX) & $\bar{x}$ & 11.70 & 12.60 & 2.80 & 1.20 & 10.00 & 5.06 \\
& $\mathrm{SD}$ & 5.40 & 3.02 & 2.85 & 1.45 & 21.24 & 5.90 \\
$\mathrm{Cs}$ (syrup) & $\bar{x}$ & $13.60^{\mathrm{A}}$ & $14.96^{\mathrm{A}}$ & $4.30^{\mathrm{B}}$ & $1.16^{\mathrm{B}}$ & $0.20^{\mathrm{B}}$ & $1.18^{\mathrm{B}}$ \\
& $\mathrm{SD}$ & 6.51 & 10.51 & 2.49 & 1.24 & 0.20 & 0.53 \\
& $\bar{x} 0$ & $13.42^{\mathrm{Aa}}$ & $5.53^{\mathrm{b}}$ & $5.52^{\mathrm{b}}$ & $1.72^{\mathrm{B}}$ & $0.28^{\mathrm{B}}$ & $2.40^{\mathrm{B}}$ \\
& $\bar{x}$ & 3.51 & 10.36 & 7.74 & 1.54 & 0.18 & 1.90 \\
\hline
\end{tabular}

$\mathrm{x}$ - arithmetic mean, $\mathrm{SD}$ - standard deviation. Homogenous groups marked with various letters differ significantly: uppercase letters - at $\mathrm{p} \leq 0.01$, lowercase letters - at $\mathrm{p} \leq 0.05$

Duplex PCR revealed only mixed (N. ceranae and N. apis) infections (AC) in worker bees from winter hive debris and in $\mathrm{HB}$ and $\mathrm{FB}$ from all groups before treatment. The species composition identified after treatment during successive tests in both $\mathrm{HB}$ and FB from different groups is presented in Tables 3 and 4 . A total of $125 \mathrm{HB}$ and FB samples $(100 \%)$ were analyzed ( 5 bee colonies per group x 5 sampling dates x 5 groups).

After the treatment HB were most frequently affected by mixed AC infections (59 samples, 47.2\%), followed by $N$. ceranae infections (29 samples, 23.2\%) and $N$. apis infections (6 samples, 4.8\%). Spores were not detected in 31 samples (24.8\%). $N$. apis spores were not observed in HB from group Cs fed sugar syrup (Table 3).

Forager bees were also most frequently affected by mixed AC infections, which were observed in 56 samples $(44.8 \%)$. N. apis infections were noted in 11 samples $(8.8 \%)$, and $N$. ceranae infections in 27 samples $(21.6 \%)$, whereas 31 samples $(24.8 \%)$ were free of infection (Table 4).

Our research indicates that after treatment the coinfections of $N$. apis and N. ceranae were predominant. However, single infections of $N$. apis and N. ceranae were also noted. The treatments were not fully effective since spores after treatment were still present, though to a lesser extent. All treatments were more effective in the control of N. apis than N. ceranae. 


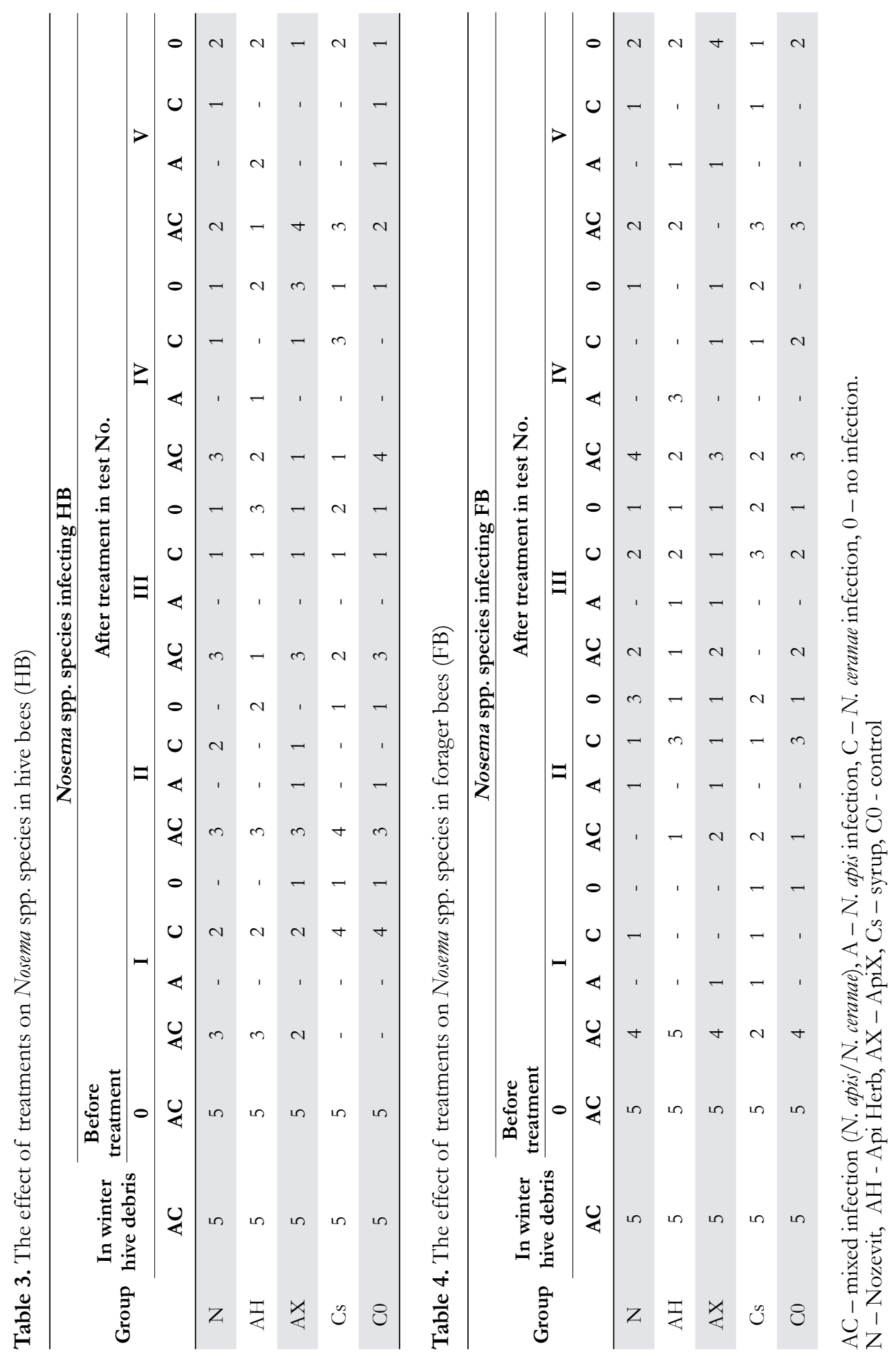




\section{DISCUSSION}

Hemocytometric analyses investigating the effect of Nozevit, Api Herb and ApiX on infected bees revealed that all of the tested treatments lowered Nosema spp. spore counts by $31.15 \%$ on average. The greatest drop in spore counts was noted in HB treated with Nozevit (67.85\%) and ApiX (63.36\%). The number of spores in FB increased by $52.41 \%$ after the administration of Nozevit and by $7.69 \%$ after ApiX treatment. The above results indicate that Nozevit delivers short-lived therapeutic effects. An increase in spore counts was observed in forager bees that need more energy to collect nectar and pollen and are more likely to be exposed to pathogenic spores in the environment.

Similar results were reported by other authors who evaluated the efficacy of different treatments in reducing Nosema. spp spore counts. In a study of Sicilian bee colonies displaying evident symptoms of nosemosis, Bessi and Nanetti [22] demonstrated that the administration of Api Herb at $4 \mathrm{~g} / 50 \mathrm{ml}$ of sugar syrup over a period of 3 weeks had reduced the number of Nosema spp. spores in worker bees by $46 \%$, whereas fumagillin decreased spore counts by $60 \%$. Valobra et al. [23] studied 3 bee groups infected with Nosema spp. spores and observed a $71.7 \%$ reduction in spore counts in the group administered Api Herb in sugar syrup, 53.6\% reduction in the group treated with fumagillin and $30.8 \%$ reduction in the control group. According to the cited authors, Api Herb decreases spore counts without exerting an adverse influence on the development of bee colonies. Gajger et al. administered Nozevit in sugar syrup and in sugar and honey cake to bee colonies infected with $N$. ceranae spores. Nozevit administered in sugar syrup decreased spore counts by $48.31 \%$ after 12 days, by $55.91 \%$ after 28 days, by $74.15 \%$ after 40 days, and by $81.92 \%$ after 60 days. When administered in sugar and honey cake, the resulting drop in spore counts reached $50.63 \%, 19.25 \%, 33.42 \%$ and $21.10 \%$, respectively. Although Nosema spp. infections were not fully suppressed, Nozevit reduced the number of spores in experimental groups relative to the control [24]. In another research Talk- Gajger et al. tested the effectiveness of Nozevit. On the 10th day after the treatment of Nosema disease with Nozevit, they observed similar percentage reductions in the number of spores in the treated colonies as in their previous testing. Gajger et al. suggested that the herbal preparation induces the production and secretion of mucous from the epithelial layer [17]. Higes et al. evaluated the efficacy of Nozevit, using experimental doses (different doses than recommended by the manufacturer). The results showed that in the experimental group after Nozevit treatment of 4 doses a week of 20 drops (1 $\mathrm{ml}$ ) in $500 \mathrm{ml}$ of sugar syrup, the number of Nosema spores decreased. Hovever, the efficacy Nozevit was lower than when fumagilin was used [18].

In this study, ApiX reduced spore counts in $\mathrm{HB}$ by $63.36 \%$, similarly as Nozevit, and it was twice as effective in eliminating nosemosis than Api Herb. A minor increase in spore counts was noted in FB (7.69\%), and it was lower than in FB from group Cs fed sugar syrup. The tested treatments did not exert negative effects on bee colonies. 
The differences in treatment effect on two Nosema species in have never been investigated for various reasons, mainly because the same insect cannot be analyzed on multiple occasions. In this study, the spores were detected microscopically during successive tests in randomly sampled bees. Duplex PCR confirmed the presence of different microsporidia species in worker bees sampled from the same colony on different dates. The above results validate our previous observations [21] that worker bees infected with different Nosema species can inhabit the same colony [25]. Meana et al. [26] also demonstrated that the origin of the sampled material plays an important role in the identification of N. ceranae spores. In the cited study, spore counts in worker bees differed subject to sampling location and sampling hour. The highest spore counts were reported in forager bees regardless of the sampling hour and in forager and hive bees that were collected around noon.

The treatments used in our research to control Nosema infection reduced the load of this pathogen in the treated groups. However, it was not fully effective, because after treatment spores were still present, though less frequently. Based on the presented data we conclude that the Nozevit, Api Herb and ApiX were more efficient to control of N. apis compared to N. ceranae.

\section{Authors' contributions}

MM participated the study design, carried out the molecular genetic and microscopic studies and drafted the manuscript. RS conceived of the study, helped to draft the manuscript and final acceptance of the manuscript. SK statistical analysis.

\section{Declaration of conflicting interests}

The author(s) declared no potential conflicts of interest with respect to the research, authorship, and/or publication of this article.

\section{REFERENCES}

1. Paxton R: Does infection by Nosema ceranae cause "Colony Colapse Disorder" in Honey bees (Apis mellifera)? J Apic Res 2010, 49: 80-84.

2. Simeunovic P, Stevanovic J, Vidanovic D, Nisavic J, Radovic D, Stanisic Lj, Stanimirovic Z: A survey ofdeformed wing virus and acute bee paralysis virus in honey bee colonies from Serbia using real-time RT-PCR. Acta Vet-Beograd 2014, 64:81-92.

3. Glavinic U, Stevanovic J, Gajic B, Simeunovic P, Đuric S, Vejnovic B, Stanimirovic Z: Nosema ceranae DNA in honey bee haemolymph and honey bee mite Varroa destructor. Acta Vet-Beograd 2014, 64:349-357.

4. Morse RA, Nowogrodzki R: Honey bee pests, predators and diseases. 1990, Cornell University Press, Ithaca, New York.

5. Gliński Z: Rzedzicki J 1993, Choroby pszczół. PWN Warszawa. 
6. Webster TC, Pomper KW, Hunti G, Thacker EM, Jones SC: Nosema apis infection in worker and queen Apis mellifera. Apidologie 2004, 35: 49-54.

7. Higes M, Garcia-Palencia P, Martin-Hernández R, Meana A: Experimental infection of Apis mellifera honeybees with Nosema ceranae (Microsporidia). J Invertebr Pathol 2007, 94: 211-217.

8. Forsgren E, Fries I: Comparative virulence of Nosema ceranae and Nosema apis in individual European honey bees. Vet Parasitol 2010, 170:212-217.

9. Milbrath MO, van Tran T, Huang W-F, Solter LF, Tarpy DR, Lawrence F, Huang ZY: Comparative virulence and competition between Nosema apis and Nosema ceranae in honey bees (Apis mellifera), J Invertebr Pathol 2015, 125:9-15.

10. Stevanovic J, Simeunovic P, Gajic B, Lakic N, Radovic D, Fries I, Stanimirovic Z: Characteristics of Nosemaceranae infection in Serbian honey bee colonies. Apidologie 2013, 44:522-536.

11. Czekońska K: The influence of Nosema apis on young honeybee queens and transmission of the disease from queens to workers. Apidologie 2000, 31: 701-706.

12. Simeunovic P, Stevanovic J, Cirkovic D, Radojicic S, Lakic N, Stanisic L, Stanimirovic Z: Nosema ceranae and queen age influence the reproduction and productivity of the honey bee colony. J Apicult Res 2014, 53:545-554.

13. Stanimirovic Z, Stevanovic J, Bajic V, Radovic I: Evaluation of genotoxic effects of fumagillin by cytogenetic tests in vivo. Mutation Res-Genet Tox 2007, 628:1-10.

14. Stevanovic J, Stanimirovic Z, Radakovic M, Stojic V: In vitro evaluation of the clastogenicity of fumagillin. Environ Mol Mutagen 2008, 49:594-601.

15. van den Heever JP, Thompson TS, Curtis JM, Pernal SF: Stability of dicyclohexylamine and fumagillin in honey. Food Chem 2015, 179:152-158.

16. Botias C, Martin-Hernandez R, Meana A, Higes M: Screening alternative therapies to control Nosemosis type C in honey bee (Apis mellifera iberiensis) colonies. Res Vet Sci 2013, 95: 1041-1045.

17. Tlak Gajger I, Kozaric Z, Berta D, Nejedli S, Petrinec Z: Effect of the herbal preparation Nozevit on the mid-gut structure of honeybees (Apis mellifera) infected with Nosema sp. spores, Vet Med-Czech 2011, 56:344-351.

18. Higes M, Gómez-Moracho T, Rodriguez-García C, Botias 321 C, Martín-Hernández R: Preliminary effect of an experimental treatment with "Nozevit ${ }^{\circledR}$ ", (a phyto-pharmacological preparation) for Nosema ceranae control. J Apicult Res 2014, 53:472-474.

19. OIE (2008) Office International des Epizooties, Manual of Diagnostic Tests and Vaccines for Terrestrial Animals, Chap. 2.2.4., Nosemosis of Honey Bees. http://www.oie.int/ fileadmin/Home/eng/Health_standards/tahm/2.02.04_NOSEMOSIS.pdf

20. Martin-Hernandez R, Meana A, Prieto L, Salvador AM, Garrido-Bailon E, Higes M: Outcome of Colonization of Apis mellifera by Nosema ceranae. Appl Environ Microbiol 2007, 73: 6331-6338.

21. Sokół R, Michalczyk M: Detection of Nosema spp. in worker bees of different ages during the flow season. J Apicult Sci 2012, 56: 19-25.

22. Bessi E, Nanetti A: Evaluation of three different strategies of Nosema control. Abstracts 39 $9^{\text {th }}$ Apimondia International Apicultural Congres 21-26 August 2005, Dublin, Ireland.

23. Valobra F, Mandelli U, Bessi E: Abstracts 39th Apimondia International Apicultural Congres 21-26 August 2005, Dublin, Ireland. 
24. Tlak-Gajger I, Vugrek O, Pinter L, Petrinec Z: „Nozevit pattiens” treatment of honey bees (Apis mellifera) for the control of Nosema ceranae disease. Am Bee J 2009, 149:1053-1056.

25. Michalczyk M, Sokol R, Szczerba-Turek A, Bancerz-Kisiel A. A comparison of the effectiveness of the microscopic method and the multiplex PCR method in identifying and discriminating the species of Nosema spp. spores in worker bees (Apis mellifera) from winter hive debris. Pol J Vet Sci 2011, 14: 385-391.

26. Meana A, Martin-Hernandez R, Higes M. The reliability of spore counts to diagnose Nosema ceranae infections in honey bees. J Apicult Res and Bee World 2010, 49:212-214.

\title{
EVALUACIJA EFIKASOSTI ODABRANIH TRETMANA INFEKCIJE SA NOSEMA SPP. HEMOCITOMETRIJSKOM METODOM I METODOM DUPLEKS PCR
}

\author{
MICHALCZYK Maria, SOKÓ£ Rajmund, KOZIATEK Sylwia
}

U proteklim godinama svedoci smo povećanja mortaliteta pčela u većem broju regiona sveta. Uočeno smanjenje populacije pčela posledica je kombinacije većeg broja faktora pri čemu infekcije sa mikrosporidijama Nosema apis i N. ceranae daju značajan doprinos ovom fenomenu. Infekcije sa ovim parazitima uslovljavaju skraćenje života pčela i smanjuju produktivnost košnice. Cilj studije je bio evaluacija efikasnosti Nozevit, Api Herb i ApiX (acetilsalicilna kiselina i ekstrakt Artemisia absinthium L) u kontroli infekcija prouzrokovanih sa Nosema spp, u terenskim uslovima. Posmatrane su dve grupe pčela radilica: radilice u košnici i radilice sakupljačice polena na ulazu u košnicu. Efekti terapija na broj spora kao i vrste mikrosporidija bili su analizirani hemocitometrijskom metodom kao i dupleks PCR metodom. Statistička analiza je pokazala da su tretmani prosečno smanjivali broj spora za 31,15\%. Kod radilica u košnici, infekcija sa Nosema spp, je najefikasnije smanjena primenom Nozevit $(67,85 \%)$ i ApiX $(63,36 \%)$ preparata. Koinfekcija (N. ceranae i N. apis) je pre tretmana potvrđena u svim uzorcima ispitivanih pčela. Međutim, posle tretmana uočene su infekcija sa pojedinačno N. apis i N. ceranae. Tretmani koji su testirani, bili su efikasniji u kontroli infekcije sa N. apis u poređenju sa kontrolom infekcije N. ceranae. 